\title{
Prenatal Expression of MET Receptor Tyrosine Kinase in the Fetal Mouse Dorsal Raphe Nuclei and the Visceral Motor/Sensory Brainstem
}

\author{
Hsiao-Huei Wu Pat Levitt \\ Department of Cell and Neurobiology, Zilkha Neurogenetic Institute, Keck School of Medicine of the University of \\ Southern California, Los Angeles, Calif., USA
}

\section{Key Words}

Autism · Motor neurons - Vagal complex · Raphe neurons ·

Synaptogenesis

\begin{abstract}
Signaling via MET receptor tyrosine kinase (MET) has been implicated in a number of neurodevelopmental events, including cell migration, dendritic and axonal development and synaptogenesis. Related to its role in the development of forebrain circuitry, we recently identified a functional promoter variant of the MET gene that is associated with autism spectrum disorder (ASD). The association of the MET promoter variant rs $1858830 \mathrm{C}$ allele is significantly enriched in families with a child who has ASD and co-occurring gastrointestinal conditions. The expression of MET in the forebrain had been mapped in detail in the developing mouse and rhesus macaque. However, in mammals, its expression in the developing brainstem has not been studied extensively throughout developmental stages. Brainstem and autonomic circuitry are implicated in ASD pathophysiology and in gastrointestinal dysfunction. To advance our understanding of the neurodevelopmental influences of MET signaling in brainstem circuitry development, we employed in situ hybridization and immunohistochemistry to map the expression of
\end{abstract}

Met and its ligand, $\mathrm{Hgf}$, through prenatal development of the mouse midbrain and hindbrain. Our results reveal a highly selective expression pattern of Met in the brainstem, including a subpopulation of neurons in cranial motor nuclei (nVII, $\mathrm{nA}$ and $\mathrm{nXII),} \mathrm{B6} \mathrm{subgroup} \mathrm{of} \mathrm{the} \mathrm{dorsal} \mathrm{raphe,} \mathrm{Barrington's}$ nucleus, and a small subset of neurons in the nucleus of solitary tract. In contrast to Met, neither full-length nor known splice variants of $\mathrm{Hgf}$ were localized in the prenatal brainstem. RT-PCR revealed $\mathrm{Hgf}$ expression in target tissues of Met-expressing brainstem neurons, suggesting that MET in these neurons may be activated by HGF from peripheral sources. Together, these data suggest that MET signaling may influence the development of neurons that are involved in central regulation of gastrointestinal function, tongue movement, swallowing, speech, stress and mood.

Copyright $\odot 2013$ S. Karger AG, Basel

\section{Introduction}

Met receptor tyrosine kinase (MET) and its ligand, hepatocyte growth factor (HGF) were first cloned approximately 30 years ago [1-5]. Initially, MET was characterized as a receptor tyrosine kinase with proto-oncogenic function and HGF (also named scatter factor) was found

\section{KARGER}

E-Mail karger@karger.com

www.karger.com/dne (c) 2013 S. Karger AG, Basel

$0378-5866 / 13 / 0351-0001 \$ 38.00 / 0$
Pat Levitt, $\mathrm{PhD}$

Zilkha Neurogenetic Institute, Keck School of Medicine of USC

1501 San Pablo Street

Los Angeles, CA 90089 (USA)

E-Mail plevitt@med.usc.edu 
as a serum- and platelet-derived protein capable of inducing cell proliferation and migration in vitro $[2,5,6]$. Expression of MET and HGF has been observed in most solid tumors and MET/HGF signaling is well characterized in human malignancies and metastasis $[7,8]$. Nonetheless, MET and HGF are also involved in the normal development and regeneration of several different organs [9-14].

More recently, MET signaling has been implicated in a number of neurodevelopmental events, including cell migration, dendritic and axonal development and synaptogenesis [see 15 for review]. Relevant to a role for MET signaling in the development of specific forebrain circuits $[16,17]$, a functional promoter variant of the $M E T$ gene is associated with autism spectrum disorder (ASD) [18-20]. The association of the MET promoter variant rs 1858830 $C$ allele is further enriched in families in which a child has ASD with co-occurring gastrointestinal conditions [21]. The MET promoter $C$ variant reduces gene transcription in vitro [18], and in postmortem brains of individuals with ASD, MET transcript and protein are significantly decreased [22, 23]. MET is currently categorized as a strong risk candidate for ASD [24] (also see SFARI Gene; https:// gene.sfari.org/autdb/GS_Home.do).

The expression patterns of MET and its transcript $(M e t)$ in mouse forebrain was mapped in detail recently [25]. We showed that the Met transcript is located in specific populations of excitatory projection neurons within the developing mouse neocortex and subcortically in a very limited number of limbic system regions. Temporally, transcript and protein expression in the forebrain is transient, first detected late in gestation, and peaking between postnatal day 7 (P7) to 14 . This is a period of active neurite outgrowth and synaptogenesis in the brain. There is strong temporal conservation of MET expression between the mouse and rhesus macaque forebrain $[15,26]$, with conserved subcortical but different regional expression in the neocortex.

Brainstem and autonomic circuitry has been implicated in ASD pathophysiology [27-31] and in central origins of gastrointestinal dysfunction [32-35]. Since the association of the $M E T$ promoter variant is further enriched in ASD with co-occurring gastrointestinal conditions [21], MET may be a point of functional convergence of these conditions. A detailed mapping of MET gene expression in the developing brainstem may reveal how the receptor may be involved in peripheral autonomic and homeostatic functions. In mice, there has been limited Met expression mapping in several motor nuclei, i.e. trochlear motor $(\mathrm{nIV})$, trigeminal $(\mathrm{nV})$, superior salivatory (part of nVII), glossopharyngeal (nIX), vagus (nX), cranial accessory (nXI), and hypoglossal nuclei (nXII), from E11 to E13 [36], at a time just after neuronal birth (>E9-10) [37]. While not examined beyond E13, these data are similar to its expression pattern in the developing forebrain, in which Met expression rises during the period of extensive neurite growth. Supporting a functional role for MET signaling in early (prior to E13) brainstem development, HGF has been shown to be a potent axon chemoattractant in mouse midbrain/hindbrain explants [36]. Furthermore, limited analysis of Met and Hgfknockout mice revealed abnormal projections of hypoglossal nerve (XII) [36] and spinal motor nerves [38]. Knockdown of Met in developing zebrafish by morpholinos leads to altered facial motor neuron migration and differentiation [39]. Nonetheless, the expression pattern and function of Met in mouse brainstem development after E13 is unclear.

The expression of HGF in the developing mammalian central nervous system (CNS) is largely unknown. HGF expression analysis is rather complex because, in addition to its full length mRNA, several splice variants have been described [40-42]. Some of these HGF splice variants can bind and activate MET $[40,41,43]$. In humans, mutations affecting several of the HGF splice variants are shown to impact hearing development [42]. The spatiotemporal regulation of MET signaling during development will depend on HGF availability in the tissue; thus, determining the developmental expression pattern of $H g f$ and its variants may help us to further understand the roles of HGF/ MET signaling in CNS development.

In this study we examined prenatal expression of $\mathrm{Met}$ and Hgf in the mouse, focusing on the brainstem. Transcript and protein mapping reveal highly selective Met expression patterns, including subpopulations of neurons involved in regulating gastrointestinal function, tongue movement, swallowing, speech, stress and mood. In contrast, $\mathrm{Hg} f$ and several of its splice variants were not detected in the brainstem but instead were expressed in peripheral targets of MET-expressing brainstem neurons. In rostral aspects of the neuraxis, we found $\mathrm{Hg}$ expression largely confined to periventricular regions of the forebrain. The developmental implications of these unique expression patterns are discussed.

\section{Materials and Methods}

Animals

CD-1 [Crl:CD-1(ICR)], Isl1 ${ }^{\text {tml(cre)Sev [44], also known as Isl1 }}{ }^{\text {cre }}$ (generously provided by Dr. Sylvia Evan at University of California, San Diego), B6.Cg-Gt(ROSA)26Sor ${ }^{t m 9(C A G-t d T o m a t o) H z e / J}$ [45], also 
known as Rosa-tdTomato ${ }^{f x}$ (purchased from The Jackson Laboratory, Bar Harbor, Me., USA), and Fev ${ }^{\text {tmlEsd }}$ [46], also known as Pet-1 (generously provided by Dr. Evan Deneris at Case Western Reserve University School of Medicine) mice were used in this study. Timepregnant CD-1 mice were purchased from Charles River, Wilmington, Mass., USA. Time-pregnant transgenic mice were bred inhouse. Mice were maintained on a 12-hour light/12-hour dark cycle with free access to food and water. The day following a time-delimited overnight pairing was considered E1. Pregnant females were deeply anesthetized with isoflurane vapors followed by rapid decapitation in order to harvest embryonic tissues. All experimental procedures using animals were approved by the Institutional Animal Care and Use Committee at the University of Southern California and conformed to US National Institutes of Health guidelines.

\section{In situ Hybridization}

For in situ hybridization (ISH), embryos were dissected in cold PBS, fixed in $4 \%$ paraformaldehyde in PBS ( $\mathrm{pH} 7.4$ ) overnight at $4^{\circ} \mathrm{C}$ and transferred to $30 \%$ sucrose/PBS for cryoprotection. Brains were embedded in TFM tissue freezing medium (Triangle Biomedical Sciences, Inc., Durham, N.C., USA) over liquid nitrogen vapors and then stored at $-80^{\circ} \mathrm{C}$ until sectioned at $20 \mu \mathrm{m}$ with a cryostat. Digoxigenin-labeled cRNA probes were: Met probe [25] (2,665-4,051 bp of GenBank No. NM_008591), mouse Hgf (176966 bp of GenBank No. AK042121), and mouse Isl1 (704-1,307 bp of GenBank No. BC132263). ISH on sections was performed as described [47]. Briefly, slides were fixed in 4\% PFA/PBS (20 min) at room temperature (RT), washed in PBS, and followed by proteinase $\mathrm{K}$ treatment $(1-1.25 \mu \mathrm{g} / \mathrm{ml}, \mathrm{RT})$ for $15 \mathrm{~min}$. Acetylation was performed by incubating slides under agitation for $10 \mathrm{~min}$ in triethanolamine (TEA-HCl, pH8.0) after drop-by-drop addition of acetic anhydrate $(0.25 \%$ of TEA volume). Slides were prehybridized for at least $2 \mathrm{~h}$ at $60^{\circ} \mathrm{C}$ in hybridization solution (50\% deionized formamide, $5 \times$ SSC, $\mathrm{pH} 7.0,1 \times$ Denhardt's solution, $0.1 \%$ Tween-20, 0.1\% CHAPS, 5 mM EDTA, pH 8.0, $100 \mu \mathrm{g} / \mathrm{ml}$ heparin, $300 \mu \mathrm{g} / \mathrm{ml}$ yeast tRNA in DepC- $\mathrm{H}_{2} \mathrm{O}$ ). The hybridization step was carried out for $16-18 \mathrm{~h}$ at $60^{\circ} \mathrm{C}$ in hybridization solution. Slides were then washed 3 times $(3 \times 45 \mathrm{~min})$ at $65^{\circ} \mathrm{C}$ in washing solution ( $2 \times$ SSC, $\mathrm{pH} 4.0,50 \%$ formamide, $1 \%$ SDS in distilled water), then $3 \times 15 \mathrm{~min}$ in TBST (25 mM Tris-HCL, pH 7.5, $136 \mathrm{~mm} \mathrm{NaCl}, 2.68$ $\mathrm{mM} \mathrm{KCl,} 1 \%$ Tween-20 in distilled water) with light agitation at RT. Slides were blocked for $1 \mathrm{~h}$ at RT with blocking reagent (100 $\mathrm{mM}$ Tris- $\mathrm{HCl}, \mathrm{pH}$ 7.5, $150 \mathrm{~mm} \mathrm{NaCl}$ containing 1.5\% blocking reagent from Roche, Indianapolis, Ind., USA), and followed by incubation at $4{ }^{\circ} \mathrm{C}$ overnight with alkaline phosphatase-conjugated anti-DIG Fab fragments (1:2,000; Roche). Color development was carried out at RT in NTMT solution ( $100 \mathrm{mM} \mathrm{NaCl}, 100 \mathrm{~mm}$ Tris$\mathrm{HCl}, \mathrm{pH}$ 9.5, $25 \mathrm{mM} \mathrm{MgCl}_{2}, 1 \%$ Tween-20, 2 mM levamisole) with $0.2 \mathrm{mM}$ 5-bromo-4-choloro-3-indolyl phosphate (BCIP) and 0.2 mM nitroblue tetrazolium (NBT; Roche).

\section{RT-PCR}

Total RNA from the E13 and E16 CD-1 mouse whole brain, the remaining head tissue, gut, whole spinal cord, or heart were extracted with an RNeasy kit (Qiagen, Valencia, Calif., USA) per manufacturer's recommendation and reverse-transcribed using oligo $(\mathrm{dT})_{20}$ primers and Superscript III reverse transcriptase (Life Technologies, Grand Island, N.Y., USA) after DNase treatment (Turbo DNA-free kit; Life Technologies). Resulting cDNAs were analyzed by PCR, using the following primers:

Met Expression in the Developing

Brainstem
panHgf: forward primer, 5'- GCATGTCCTCCTGCACCTCCTCCTGCT -3'; reverse primer, 5' - TCCCCCTTCTTCCCCTCGAGGATTT-CG - $3^{\prime}$.

NK1: forward primer, $5^{\prime}$ - TGGGGGACCAAACTTCTGCCGGTCCT -3'; reverse primer, 5' - CGTCGGGGTAGCACCCCATGTGA - $3^{\prime}$.

Intron4: forward primer, 5'-CCCTCGGGGTTTGCATACTG-3'; reverse primer, 5'-CTGGGTGTTCCCCCTCCTTT-3'.

\section{Immunostaining}

Embryos, processed as for in situ analysis, were cryosectioned at 12 or $20 \mu \mathrm{m}$; sections were permeabilized and blocked with $0.3 \%$ Triton X-100 in 5\% normal donkey serum (Jackson ImmunoResearch Laboratories, West grove, Pa., USA) and incubated overnight at $4{ }^{\circ} \mathrm{C}$ with primary antibodies: goat anti-MET (final concentration: $2 \mu \mathrm{g} / \mathrm{ml}$; R\&D systems, Minneapolis, Minn., USA; AF527); 1:1,000 rabbit anti-serotonin (5-HT; final concentration: $58 \mu \mathrm{g} / \mathrm{ml}$; Sigma, St. Louis, Mo., USA; S5545); 1:1,000 rabbit antityrosine hydroxylase (TH; Millipore, Billerica, Mass., USA; AB152); 1:1,000 rabbit anti-corticotropin-releasing hormone (CRH; kind gift of Dr. Ann Silverman at Columbia University College of Physicians and Surgeons); 1:200 rabbit anti-peripherin (Millipore AB 1530), and 1:50 rabbit anti-Pax2 (Invitrogen, Calif., USA; 18-0483). After extensive washing in PBS with $0.2 \%$ Tween-20, slides were incubated at RT for $1 \mathrm{~h}$ in secondary antibodies: Alexa 488-conjugated donkey anti-rabbit (1:200; Life Technologies), biotin-conjugated donkey anti-goat (1:500, Jackson ImunoResearch Laboratories), and Dylight488- or Dylight549conjugated streptavidin (1:500; Jackson ImmunoResearch Laboratories).

\section{Anatomical Mapping and Light Microscopy}

The anatomical labeling of brainstem structures were determined by comparing the expression patterns on serial sections from several experiments with the Chemoarchitectonic Atlas of the Developing Mouse Brain of Jacobowitz and Abbott, 1997 [48] and with Isl1 expression on adjacent sections at E13 (online suppl. fig. 1; see www.karger.com/doi/10.1159/000346367 for all online suppl. material). Terminology conformed to that used in the referenced atlas as well as Caton et al., 2000 [36]. Images were acquired with a Zeiss AxioCam MRm camera (Carl Zeiss, USA), using Zeiss Axiovision 4.1 software (Zeiss). Figures were prepared digitally in Adobe Photoshop CS5.1 (Adobe Systems Incorporated, San Jose, Calif., USA).

\section{Results}

\section{Met Expression in the Cranial Motor Nuclei at Late Gestational Stage}

Previously, it was shown that Met is expressed by subsets of cranial motor nuclei in the early developing brainstem (mouse E11-E13) [36]. To determine whether expression of Met mRNA in these motor nuclei persists after E13, we performed ISH on serial coronal sections at $\mathrm{E} 13,15,17$ and P0. $\mathrm{Met}^{+}$regions were defined by the expression patterns on serial sections from several experi- 


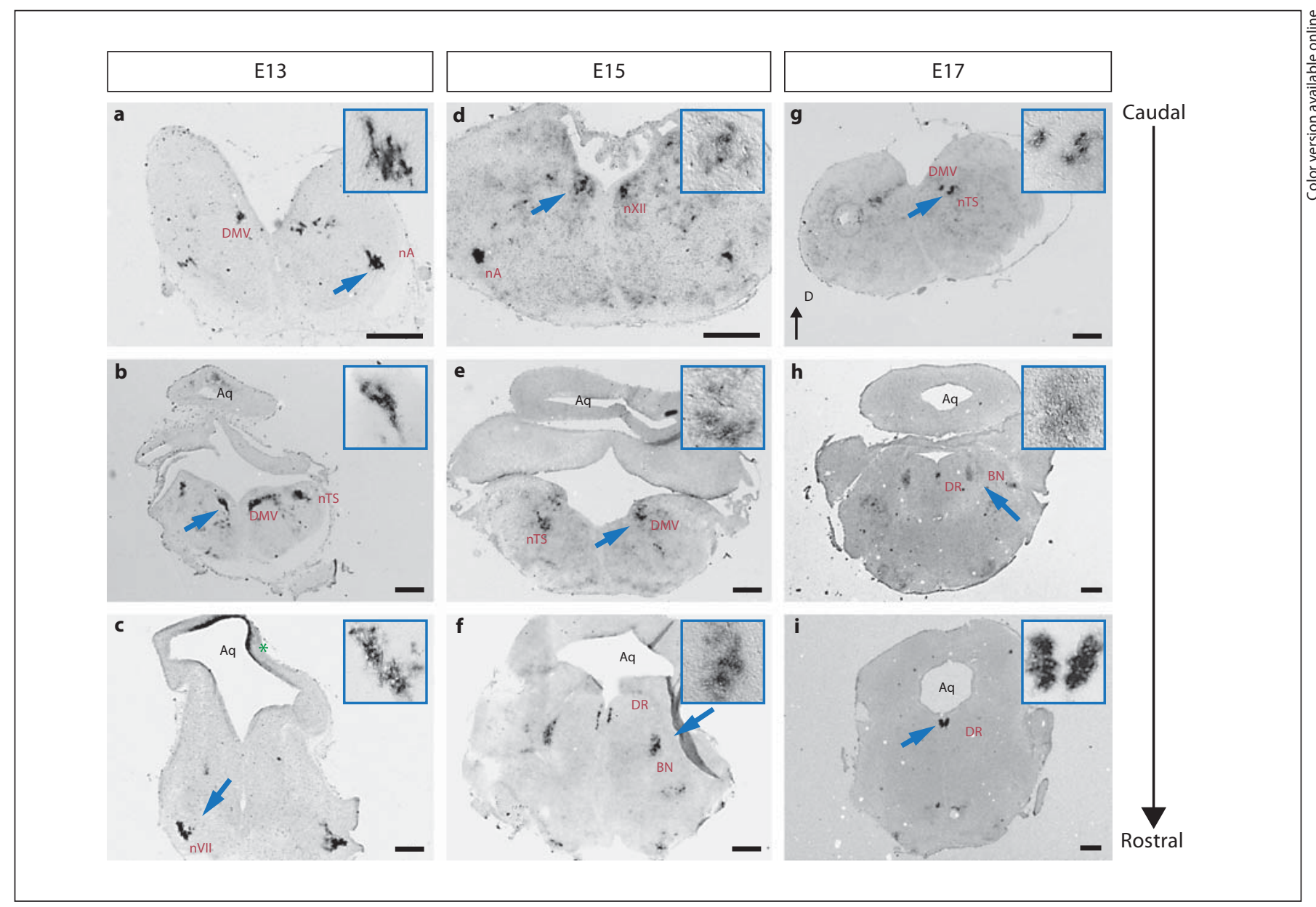

Fig. 1. Distribution of Met mRNA in the developing mouse brainstem. Series of coronal sections through the caudo-rostral extent of E13 (a, b, c), E15 (d, e, f) and E17 ( $\mathbf{g}, \mathbf{h}, \mathbf{i})$ brainstem hybridized with DIG-labeled riboprobe to the MET. Arrows point to areas shown at higher magnification (boxed). Dorsal (D) is to the top. $\mathrm{DMV}=$ Dorsal nucleus of the tenth nerve (motor, vagus); $\mathrm{nA}=$ ambiguous nucleus; $\mathrm{aq}=$ aqueduct; $\mathrm{nVII}=$ nucleus of the seventh nerve; $\mathrm{nXII}=$ nucleus of the twelfth nerve (hypoglossal). Met ex- pression was also detected in the superior colliculus (asterisk). The anatomical labeling of brainstem structures were determined by comparing the expression patterns on serial sections from several experiments with the Chemoarchitectonic Atlas of the Developing Mouse Brain [48] and with Isl1 expression on adjacent sections at E13 (online suppl. fig. 1). Scale bar $=30 \mu \mathrm{m}$. Insets: a-d, g magnified $\times 3$; e, f, $\mathbf{h}, \mathbf{i}$ magnified $\times 4$. ments and the locations confirmed with the Chemoarchitectonic Atlas of the Developing Mouse Brain [48] (fig. 1). At all ages examined, Met transcripts were detected in regions overlapping with subsets of motor nuclei (fig. 1ae, g). In all nuclei that were labeled, it appeared that not all the neurons in a specific nucleus were $\mathrm{Met}^{+}$. To confirm this, we compared the location of Met-expressing neurons with that of Isll detected on adjacent sections (online suppl. fig. 1a-f). Isl1 is expressed by all cranial motor neurons at early prenatal ages, and has been widely used as a marker of developing cranial motor neurons in several species [36, 49]. By comparing labeling patterns of Met with Isl1 expression regions, we found that at E13, Met transcripts were somatically localized to brainstem regions containing the dorsal motor nucleus of the tenth nerve (DMV or dmnX), nucleus ambiguous (nA; the motor nucleus of the spinal accessory, XI, glossopharyngeal, $\mathrm{IX}$, and vagus nerves, $\mathrm{X}$ ), nucleus of the hypoglossal nerve (nXII), as well as the nucleus of the facial nerve (nVII) (fig. 1a-c; table 1). This is in agreement with the previous report [36] showing that Met transcripts are present in subset of cranial motor nuclei. Furthermore, similar to that observed previously by Caton et al. [36], Met expression in nVII did not label the neurons of branchial motor 
division. Rather, stained neurons occupied a position lateral to this region. The position of these $\mathrm{Met}^{+}$neurons appears to overlap with the developing superior salivatory nucleus (visceral motor of nVII; fig. 1c). Interestingly, Met staining was either very weak or absent in neurons residing in the oculomotor (nIII), trochlear (nIV) and trigeminal nuclei (nV) (online suppl. fig. 1g, and data not shown). This finding was surprising, given that expression of the Met transcript was reported in limited number of neurons present within the boundaries of $\mathrm{nVI}$ and $\mathrm{nV}$ from E11 to E13 [36]. It is possible that Met expression in these nuclei is below levels of detection on 20 $\mu \mathrm{m}$ sections compared with whole-mount tissues used in previous studies.

We were most interested to know whether Met expression in these motor nuclei was maintained at E15 and beyond. We observed that with the exception of nVII, in which Met mRNA levels greatly diminished after E13, expression of the transcript was evident at E15 and E17 (fig. 1d, e, g). However, by P0, detectable Met transcript labeling in neurons located within regions of $\mathrm{nA}, \mathrm{DMV}$ and nXII had largely disappeared (table 1).

In a second set of developmental mapping studies, we used an antibody to MET combined with an endogenous fluorescent reporter strategy in order to more precisely determine the cellular localization of the MET protein. Immunofluorescence staining was performed on sections through the midbrain and hindbrain from $I s l 1^{\text {cre }} /$ RosatdTomato ${ }^{f x /+}$ embryos obtained by crossing Isl $1^{\text {cre/+ }}$ mice [44] with Rosa-tdTomato ${ }^{f x / f x}$ mice [45]. In Isl1 ${ }^{\text {cre }} /$ Rosa-tdTomato $^{f x /+}$ embryos, all neurons in cranial motor nuclei express tdTomato, which we confirmed by double staining using an antibody directed against peripherin, a peripheral and motor neuron-specific type III intermediate filament that is widely used as a marker for postmitotic cranial motor neurons [50-52] (online suppl. fig. 2, and data not shown). Cellular immunolocalization of MET was compared with neuronal labeling of cranial motor nuclei by tdTomato. Similar to ISH observations, at E16 only a subpopulation of neurons in the DMV, nXII and $\mathrm{nA}$ was both tdTomato ${ }^{+}$and $\mathrm{MET}^{+}$(fig. 2). In DMV, double-immunopositive neurons tended to be located in ventral regions (fig. 2j, k, arrowheads). No MET immunoreactivity was found colocalized with tdTomato ${ }^{+}$in nIII, $\mathrm{nIV}, \mathrm{nV}$ and $\mathrm{nVI}$ (online suppl. fig. 3). As noted previously for forebrain neurons [25], MET protein was located at a cellular level in both neuronal somata (fig. 3, arrowheads) and their axons, which were evident coursing through the brainstem toward the periphery (white arrows).

Met Expression in the Developing Brainstem
Table 1. Summary of Met expression in the midbrain/hindbrain nuclei at different developmental periods

\begin{tabular}{lllll}
\hline Nuclei & Function & E13 & E14-E17 & E18-P0 \\
\hline nVII & GVE, SVA, SVE/BE & + & $+/-$ & - \\
nA & SVE/BE & + & + & $+/-$ \\
DMV & GVA, GVE, SVA & + & + & $+/-$ \\
nXII & GSE & + & + & $+/-$ \\
nTS & GVA & + & + & $+/-$ \\
BN & visceral related, stress related & - & + & $+/-$ \\
DR & stress related, mood, & - & + & + \\
& autonomic regulation & & & \\
\hline
\end{tabular}

GVE $=$ General visceral efferent: regulates autonomic innervation of smooth muscles, cardiac muscles and glands; SVA = special visceral afferent: mediate sensations of taste from tongue; SVE/ $\mathrm{BE}=$ control gill-related muscles of face, pharynx, larynx and neck; GVA = general visceral afferent: mediates sensations of pain and temperature from visceral organs; GSE = general somatic efferent: controls muscles derived from glossal muscles.

$+=$ Expression detected; $-=$ no expression detected; $+/-=$ weak expression detected.

\section{Met Expression in Other Midbrain/Hindbrain Nuclei}

In addition to cranial motor nuclei, Met transcripts were detected in several other midbrain/hindbrain nuclei that had not been described previously. Specific Met neuronal expression was observed in regions that coincided with the nucleus of solitary tract (nTS), the caudal part of the dorsal raphe (DR), and in a group of neurons near the locus coeruleus (LC), later identified as Barrington's nuclei (BN). The spatiotemporal patterns of Met expression in these various nuclei are detailed below:

Nucleus of Solitary Tract. ISH consistently showed Met transcripts were present from E13 to E17 in a group of neurons located lateral to the DMV (fig. 1b, e, g). At E16, MET immunostaining in Isl1 ${ }^{\text {cre }} /$ Rosa-tdTomato ${ }^{f x /+}$ mice revealed the presence of $\mathrm{MET}^{+} /$tdTomato $^{-}$neurons lateral to the $\mathrm{MET}^{+} /$tdTomato $^{+}$DMV neurons (fig. $2 \mathrm{k}$, arrow). Based on their position in the developing brainstem, these may constitute a subpopulation of neurons within the nTS. The nTS is a brainstem sensory nucleus that sends an input from the facial nerve (VII), as well as receiving afferents from glossopharyngeal (IX) and vagus (X) nerves [53]. The nTS emerges rostrally from the dorsomedial edge of the spinal trigeminal nucleus and extends caudally to the border of the spinal cord [54]. It has been shown that, during development, nTS neurons can be subdivided to 2 main groups based on the combination of transcription factors expressed [55]. At E13, the major- 


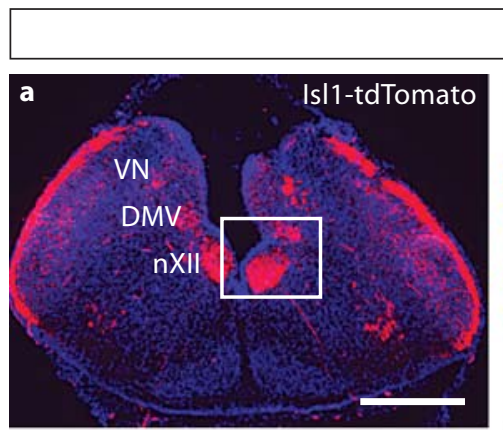

E16
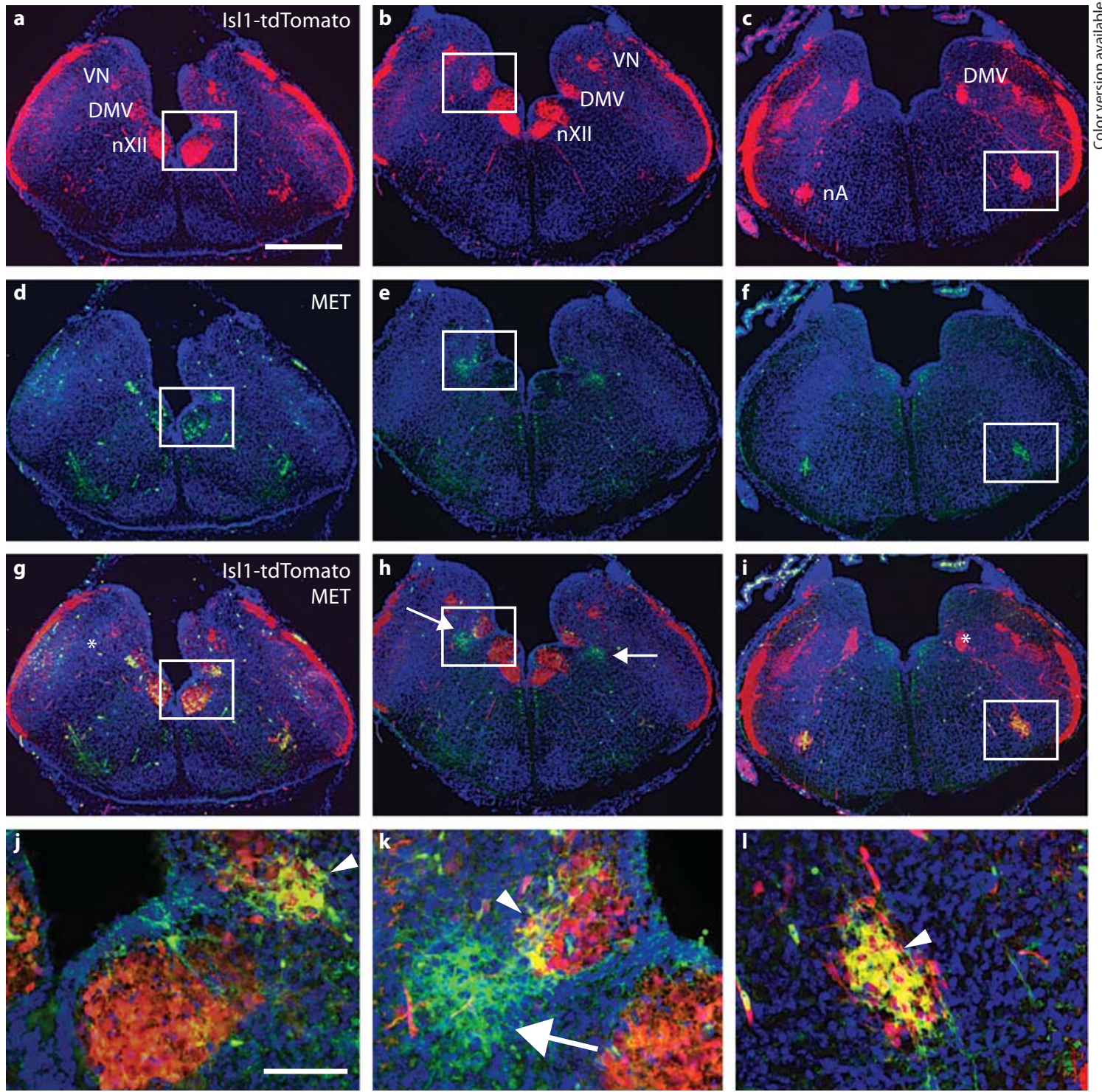

Fig. 2. MET protein expression in neurons residing in DMV, nXII and nTS. Micrographs show MET immunofluorescence in a series of coronal sections harvested from Isl1cre/Rosa-tdTomato ${ }^{f x /+}$ mice at E16. a-c Endogenous tdTomato fluorescence expressed under the control of Isll cre at 3 successive levels of the medulla. $\mathbf{d - f}$ MET immunostaining on the same sections. g-i Overlay of tdTomato and MET immunofluorescence. Regions in white boxes are presented at higher magnification in $\mathbf{j}-\mathbf{I}$. $\mathrm{VN}=$ Vestibular nucleus.
Arrowheads indicate subsets of $\mathrm{MET}^{+} / \mathrm{tdTomato}^{+}$neurons in $\mathrm{nX}$ $(\mathbf{j}, \mathbf{k})$ and in $\mathrm{nA}(\mathbf{I})$. Arrows point to a subset of $\mathrm{MET}^{+} / \mathrm{tdTomato}^{-}$ neurons located lateral to DMV. An almost complete overlap of tdTomato and MET immunofluorescence is observed in the nA (I). No MET immunoreactivity was found in the main VN ( $\mathbf{g})$ and in rostral part of DMV (i), which is indicated by an asterisk. Scale bar $=50 \mu \mathrm{m}(\mathbf{a}-\mathbf{i}) ; 10 \mu \mathrm{m}(\mathbf{j}-\mathbf{I})$. ity of nTS neurons express Phox $2 b$, but a small subset of nTS neurons arising in rhombomere 7 (where DMV nuclei are located during early developmental stage) does not express Phox $2 b[55,56]$. Instead these neurons express Pax2 [55]. We found that, at E13, the $\mathrm{MET}^{+}$neurons adjacent to the DMV expressed Pax2 (online suppl. fig. 4), suggesting that they are situated within the developing nTS. As in the case of other nuclei, MET labeling was present only in a small subpopulation of nTS neurons. 

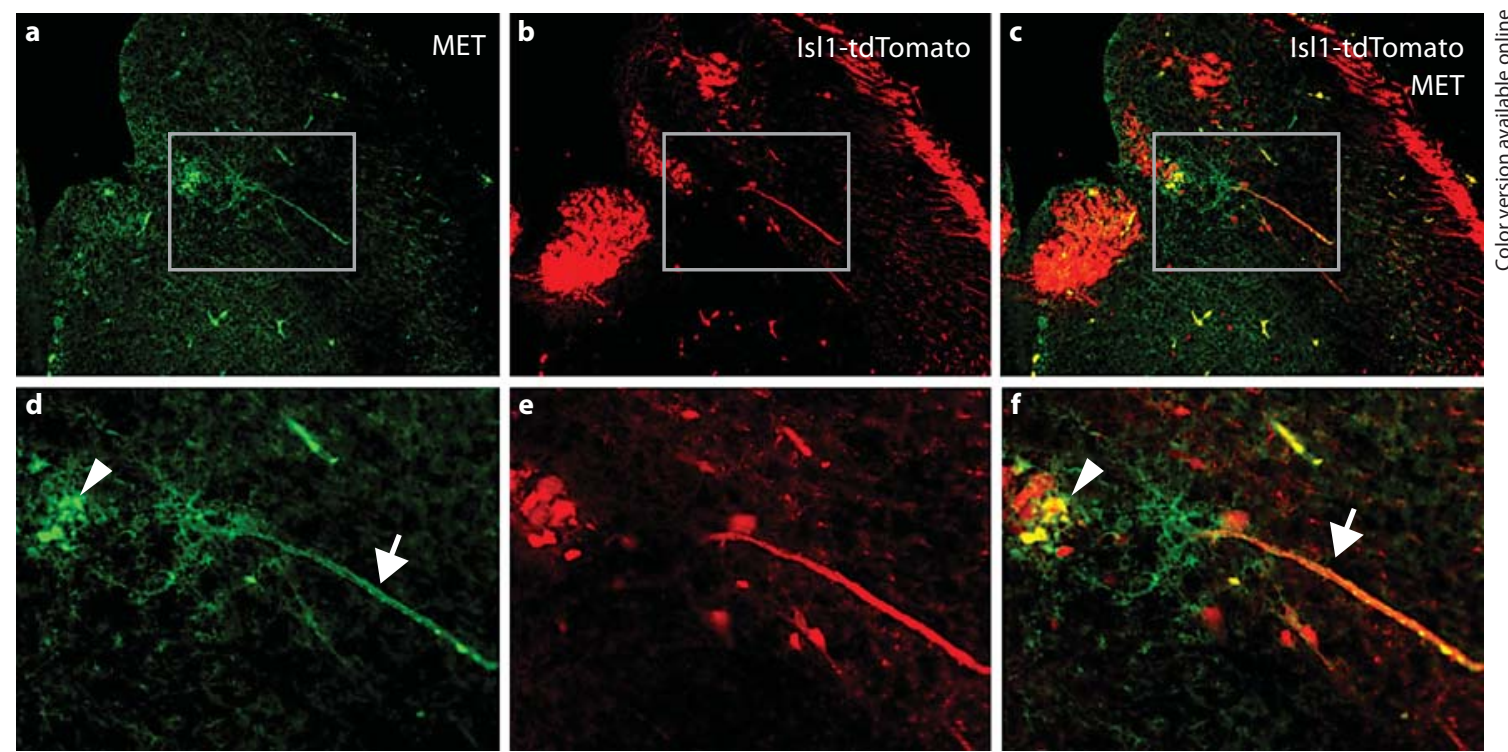

Fig. 3. MET protein is localized to somata and axons in a subpopulation of ventrolaterally situated neurons within the boundary of DMV. Higher magnifications of boxed areas in a-c are shown in $\mathbf{d}-\mathbf{f}$. Immunostaining for $\operatorname{MET}(\mathbf{a}, \mathbf{d})$ was performed on hindbrain section harvested from Isl-1cre/Rosa-tdTomato ${ }^{\text {fx/+ }}$ E16 embryos. a, d MET immunoreactivity. b, e tdTomato fluorescence. c, f Overlay. Arrowheads point to $\mathrm{MET}^{+} / \mathrm{tdTomato}^{+}$ soma and arrows to axons that are double-labeled by anti-MET and tdTomato.

$D R$ Nuclei. Specific expression of Met in the DR region first emerged by E15 (fig. 1f). Intense Met mRNA expression was maintained in DR neurons up to P0 (fig. 1h, i; table 1). Double-label immunostaining with antibodies against MET and 5-HT showed that MET immunoreactivity was present in a subset of DR 5-HT neurons (fig. 4 a-f). When examined under higher magnification, all of the $\mathrm{MET}^{+}$neurons in DR were $5 \mathrm{HT}^{+}$(fig. $4 \mathrm{~g}-\mathrm{i}$ ). Staining of serial coronal sections at E16 and sagittal sections from E16 to P4 showed that MET was expressed mainly in the caudal part of DR as paired nuclei situated just below the aqueduct (fig. $4 a-c, j-1$ ). Based on their rostrocaudal and dorsoventral locations, 5-HT neurons within the midline raphe nuclei are divided into 9 subgroups, B1-9, in the adult rat [57]. The $\mathrm{MET}^{+}$neurons were located in a region of the DR that includes the B6 and B7 groups. B6, also designated as nucleus raphe dorsalis caudalis [58], lies caudal to B7. Unlike B7, whose nuclei are partially fused in the midline at E17-E18 in rat (approximately E15-E16 for mouse) and completely fused at P1, B6 nuclei remain paired in adulthood [59]. Judged by the position (caudal aspect of DR) and the paired nuclei where they were observed (fig. 1f, h, i, 4a, b, j-l), the $\mathrm{MET}^{+} / 5-\mathrm{HT}^{+}$neurons most likely belong to the B6 serotonergic subgroup. To further delineate which subset of 5-HT neurons express
MET, double immunostaining on sections from Pet-1 knockout mice (Pet-1KO) was performed. The ETS oncogene family protein, Pet-1 (also known as FEV), is expressed in all 5-HT neurons in DR (fig. $4 \mathrm{~m}, \mathrm{n}$ ) and is required for the differentiation of approximately $70 \%$ of 5 -HT neurons in the raphe (fig. $4 \mathrm{n}$, arrowhead) [46]. Remarkably, there was no detectable MET expression in the DR of homozygous Pet-1 null mice (fig. $4 \mathrm{~d}$, arrow), even though residual $5-\mathrm{HT}^{+}$neurons were observed (fig. 4n, arrowhead). These data suggest that MET expression in B6 subgroup of DR 5-HT neurons is Pet-1 dependent.

Barrington's Nucleus. ISH staining revealed that Met mRNA expression was evident for a brief prenatal time period at E15 and E17 in the lateral pons at the level of the LC; labeling was not detectable by P0 (fig. 1f, h). Based on this localization, we initially suspected that Met was expressed in the TH-containing LC neurons (fig. 5). Surprisingly, double immunostaining revealed that $\mathrm{MET}^{+}$ and $\mathrm{TH}^{+}$neurons were completely exclusive of each other (fig. 5b, c). Instead, $\mathrm{MET}^{+}$neurons were located medial to the LC, overlapping with neurons in the BN. BN regulates several visceral organs and is a central regulator of micturition [60-63]. Neurons in the BN express CRH [64-66]. In order to verify that MET is expressed in BN neurons, we performed double immunostaining with an- 


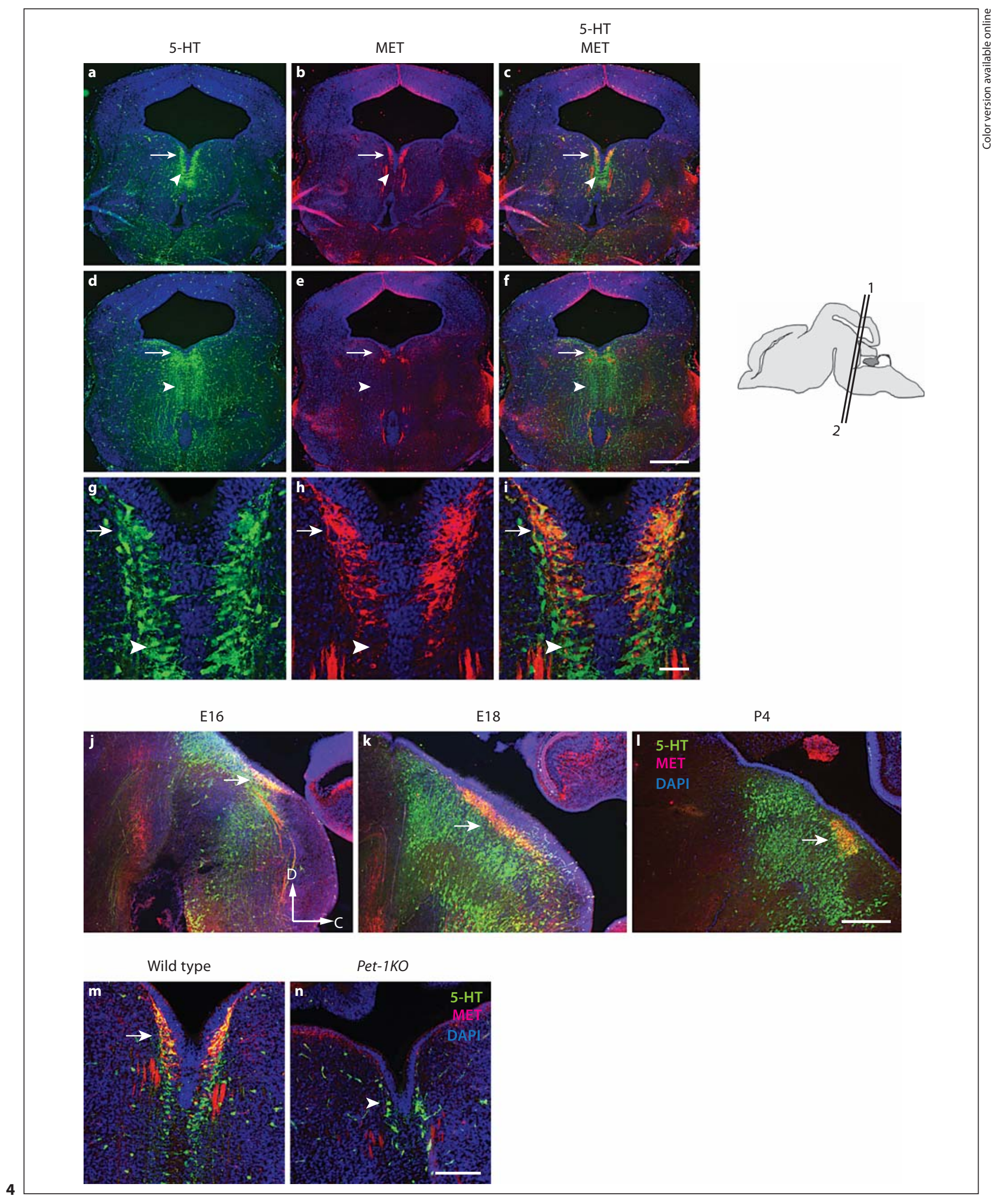


ti-MET and anti-CRH antibodies. Colocalization confirmed that nearly all $\mathrm{CRH}^{+}$neurons of $\mathrm{BN}$ expressed MET (fig. 5c-f).

HGF Is Expressed in the Developing Pineal Gland and Cells Lining the Lateral Ventricles

HGF is the only known ligand for MET $[67,68]$. To detect $H g f$ transcripts, two DIG-labeled riboprobes encompassing nonoverlapping regions of mouse $\mathrm{Hgf} \mathrm{cDNA}$ were used (online suppl. fig. 5a). Confirming specificity, both $H g f$ riboprobes readily detected $H g f$ expression in limb buds, as described previously (online suppl. fig. 5b) [38]. Furthermore, both probes used separately on adjacent sections yielded identical expression patterns (data not shown). Therefore, only ISH probe No. 1 was used in subsequent experiments. In the forebrain, we detected $\mathrm{Hgf}$ expression in the dorsal pallium at E15 and present through $\mathrm{P} 0$, the last age examined. More specifically, $\mathrm{Hgf}$ transcripts were confined to cells residing along the ventricular surface at the pallio-subpallial boundary at E15 (fig. 6a, b), where radial glial fibers originate [69]. After E15, expression of $H g f$ extended through the entire ventricular/subventricular zone (fig. $6 \mathrm{c}-\mathrm{f}$ ). $H g f$ expression was also detected weakly in the developing epithalamus that contains the emerging pineal gland at E13. Staining became very intense by E15 and remained at high levels through the end of gestation (fig. 6a, c, e).

Fig. 4. MET expression in the caudal DR serotonergic neurons is Pet-1 dependent. a-i Immunostaining for MET and 5-HT on E16 coronal sections through the midbrain in CD-1 mice. a, d, g Immunostaining with 5-HT antibody. b, e, h Immunostaining with MET antibody. c, $\mathbf{f}$, i Merged images of 5-HT and MET immunostaining. a-c are taken from the same section; $\mathbf{d - f}$ are taken from the same section. The corresponding plane of section is indicated on the cartoon showing a sagittal view on the right. a-c correspond to ' 1 '; $\mathbf{d}$-f correspond to ' 2 '. $\mathbf{g}$-i are higher-magnification images of the of DR region pictured in a-c. Arrows denote $\mathrm{MET}^{+} / 5-\mathrm{HT}^{+}$ neurons. Arrowheads denote $5-\mathrm{HT}^{+} / \mathrm{MET}^{-}$neurons. j-I MET-expressing 5-HT neurons are located at the caudal region of the DR. Immunostaining for MET and 5-HT on sagittal sections from E16, E18 and P4 brain. Dorsal (D) to the top; caudal (C) to the right. $\mathbf{m}, \mathbf{n}$ MET expression in 5-HT neurons requires Pet-1. In Pet-1KO mice, no MET expression was observed in the DR. Arrow indicates the MET-expressing serotonergic neurons in DR in E15 wild-type mice. Arrowhead denotes the residual serotonergic neurons in the Pet-1KO. No MET protein was localized in these Pet-1-independent 5-HT neurons. Scale bar $=50 \mu \mathrm{m}(\mathbf{a}-\mathbf{f}, \mathbf{j}-\mathbf{I}) ; 5 \mu \mathrm{m}(\mathbf{g}-\mathbf{i}) ; 30 \mu \mathrm{m}$ $(\mathbf{m}-\mathbf{n})$.

Met Expression in the Developing

Brainstem
HGF Is Expressed in Target Tissues of MET ${ }^{4}$

\section{Brainstem Neurons}

The expression pattern of $\mathrm{Hgf}$ in the hindbrain/midbrain was also investigated by ISH at E13, 15, 17 and 19 . Unexpectedly, we did not detect any $\mathrm{Hg}$ transcript in the developing hindbrain and midbrain (fig. 6j-1, and data not shown) at any age tested. We reasoned that like spinal motor neurons that utilize somite-derived $\mathrm{Hgf}$ [38], $\mathrm{MET}^{+}$motor neurons in the brainstem might utilize peripheral sources of HGF. Using RT-PCR, $H g$ transcripts were detected at E16 in the developing gut (innervation target for DMV and some nA neurons), heart (nA neurons), head mesenchymal/muscle tissues (neurons residing in $\mathrm{nVII}, \mathrm{nXII}$ and $\mathrm{nA}$ ), as well as the developing spinal cord (neurons in BN) (fig. 7b, c). Thus, $\mathrm{Hgf}$ transcripts were present in peripheral tissues specifically targeted by MET-expressing brainstem neurons at E16.

\section{Dynamic Expression of Hgf Alternative Spliced}

\section{Variants in the Embryonic Brain}

Alternative spliced variants of $H g f$ are capable of binding and activating the MET receptor [40, 41, 43]. These variants, however, are not detectable using our Hgf riboprobe (fig. 7a; online suppl. fig. 5); thus, their expression in the developing brain remains to be investigated. There are ten known mouse $H g f$ transcripts encoding 4 different protein isoforms reported in the UCSC mouse genome browser (fig. 7a). Isoforms 1 and 2 (detectable with the probes used in this study) encode the full-length proHGF that can be activated via membrane-bound proteases. Isoform 3 encodes a truncated version of HGF (also called HGF/NK1) [70] and was shown to bind and transduce downstream signals through MET in cultured cells. Isoform 4 encodes an even shorter form of HGF (compared to NK1) and its ability to interact with MET has never been determined. Two primer sets were designed to detect the presence of isoform 3 and 4 (fig. 7a) via RT-PCR. As shown in figure $7 \mathrm{c}, \mathrm{Hgf} / \mathrm{NK} 1$ transcripts were expressed in both brain and head tissues at E16 and in head tissue only at E13; $H g f$ isoform 4 cDNA was detected in E13 head tissues only. Interestingly, direct sequencing of the PCR products revealed two Hgf/NK1 splice variants, both using the alternative exon 5 splice site (one includes exon $5 \mathrm{a}$ and the other exon $5 \mathrm{~b}$; see fig. $7 \mathrm{a}$, isoform 3 and isoform $3^{*}$ ). The data thus reveal a complex combination of alternatively spliced forms of $H g f$ that are expressed in the developing embryonic brain and head tissue, which could serve as ligands for activating MET. 
Fig. 5. MET is expressed by neurons in $\mathrm{BN}$. a-c Immunostaining for MET, TH and $\mathrm{CRH}$ at E16. Arrowhead denotes $\mathrm{MET}^{+}$ neurons situated medial to the $\mathrm{TH}^{+} \mathrm{LC}$. Note the absence of double-labeled neurons. The arrow in $\mathbf{a}$ indicates $\mathrm{MET}^{+}$neurons in the DR. d-f In contrast, immunostaining for $\mathrm{CRH}$ and MET revealed colocalization in neurons residing within $\mathrm{BN}$ (arrowhead), but not in the more laterally situated LC (arrow). Scale Bar $=30 \mu \mathrm{m}$ (top); $10 \mu \mathrm{m}$ (bottom).
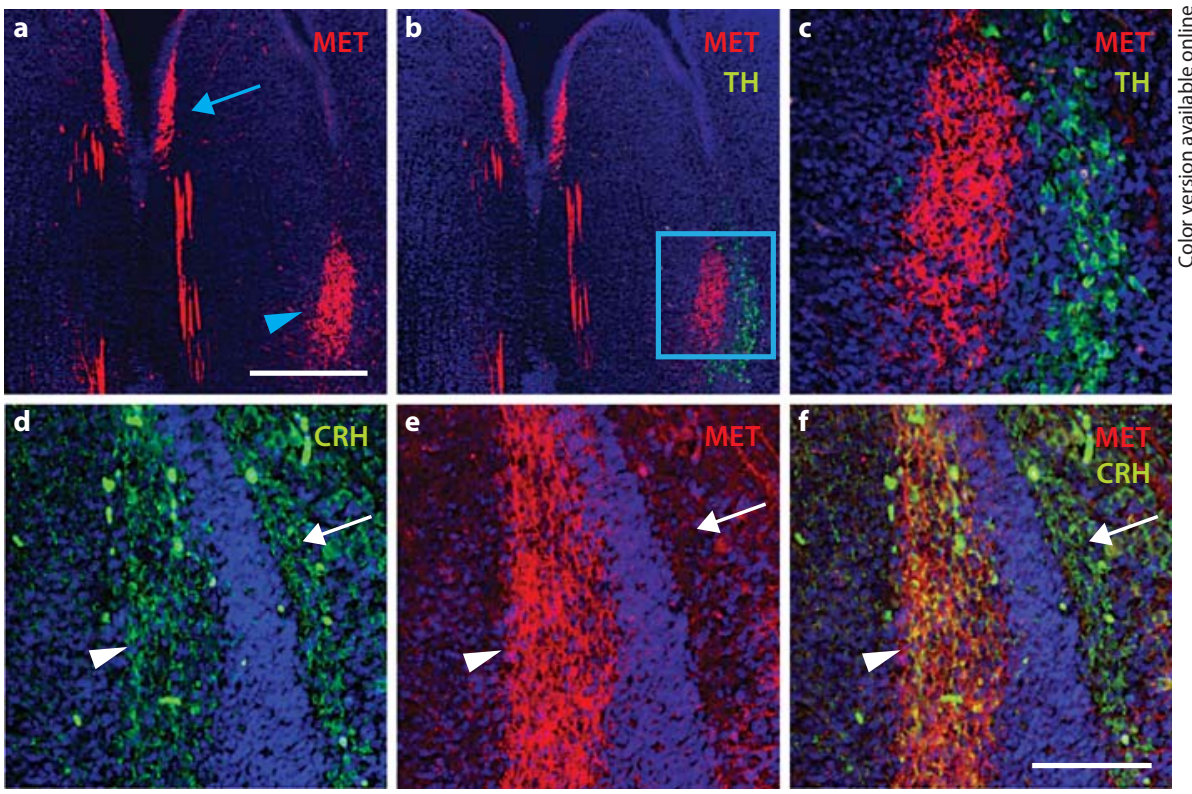

\section{Discussion}

The present study reveals specific spatiotemporal expression patterns of Met transcript, protein and multiple splice variants of $H g f$ transcripts in the developing fetal mouse brainstem. The data reveal several new potential MET ligand sources, including full-length HGF in peripheral regions targeted by $\mathrm{MET}^{+}$brainstem motor neurons, and locally expressed alternative splice forms of the ligand. The data demonstrate a relatively selective and transient pattern of Met expression in developing brainstem sensory and motor neurons that are part of complex circuits that participate in visceral organ (e.g. DMV, nA, BN and nTS) and oral functions (nVII, nA and nXII). While challenging to do precisely in fetal development, neuronal position, axonal trajectories and synaptic targets are used to categorize cranial motor neurons as somatic motor, branchiomotor or visceral motor [36]. Our results indicate that Met/MET expression in the brainstem is located mainly in subpopulations of neurons that reside in branchiomotor and visceral motor nuclei. Most interestingly, Met expression was also observed in neurons situated in two brainstem nuclei involved in homeostatic, mood and stress regulation, the $\mathrm{B} 6$ subgroup of the $\mathrm{DR}$ and $\mathrm{BN}$. We found consistently that within each labeled nucleus, Met was only expressed in specific subsets of neurons, verified by using double-labeling strategies with specific markers of neuronal subtypes (see below). Surprisingly, we did not detect any Met transcript or protein in the trigeminal nu- cleus $(\mathrm{nV})$ and observed only very faint in situ signals in the trochlear motor nucleus (nIV) (online suppl. fig. 1g, and data not shown). Using whole-mount tissue, Canton et al. [36] reported colocalization of Met and Isl1 expression in these two nuclei between E11 and E13. However, detailed illustration of the staining was not provided in that report, making it difficult to determine the extent of Met expression in these nuclei. Using our in situ and immunolocalization methods on tissue sections, the results suggest that $\mathrm{nV}$ and $\mathrm{nIV}$ cranial nerve nuclei do not express detectable levels of MET after E13, though we cannot rule out that some cells with very weak Met expression could be present in these nuclei.

Importantly, our study reveals the existence of several new potential sources of HGF ligand capable of activating MET receptor expressed prenatally by brainstem neurons. Whereas MET-expressing forebrain neurons may utilize full-length $H g f$ expressed locally, peripheral and local alternatively spliced forms of $\mathrm{Hg}$ may serve the signaling requirements of MET in the developing brainstem. Differences in distribution patterns of alternatively spliced forms of HGF suggest that MET signaling may perform different functions in the forebrain and hindbrain during development.

\section{MET, HGF and the Visceral Sensory/Motor Connection}

Our results reveal the expression of Met in neurons located in developing DMV, nA, nTS and BN. These nu-
$\mathrm{Wu} /$ Levitt 


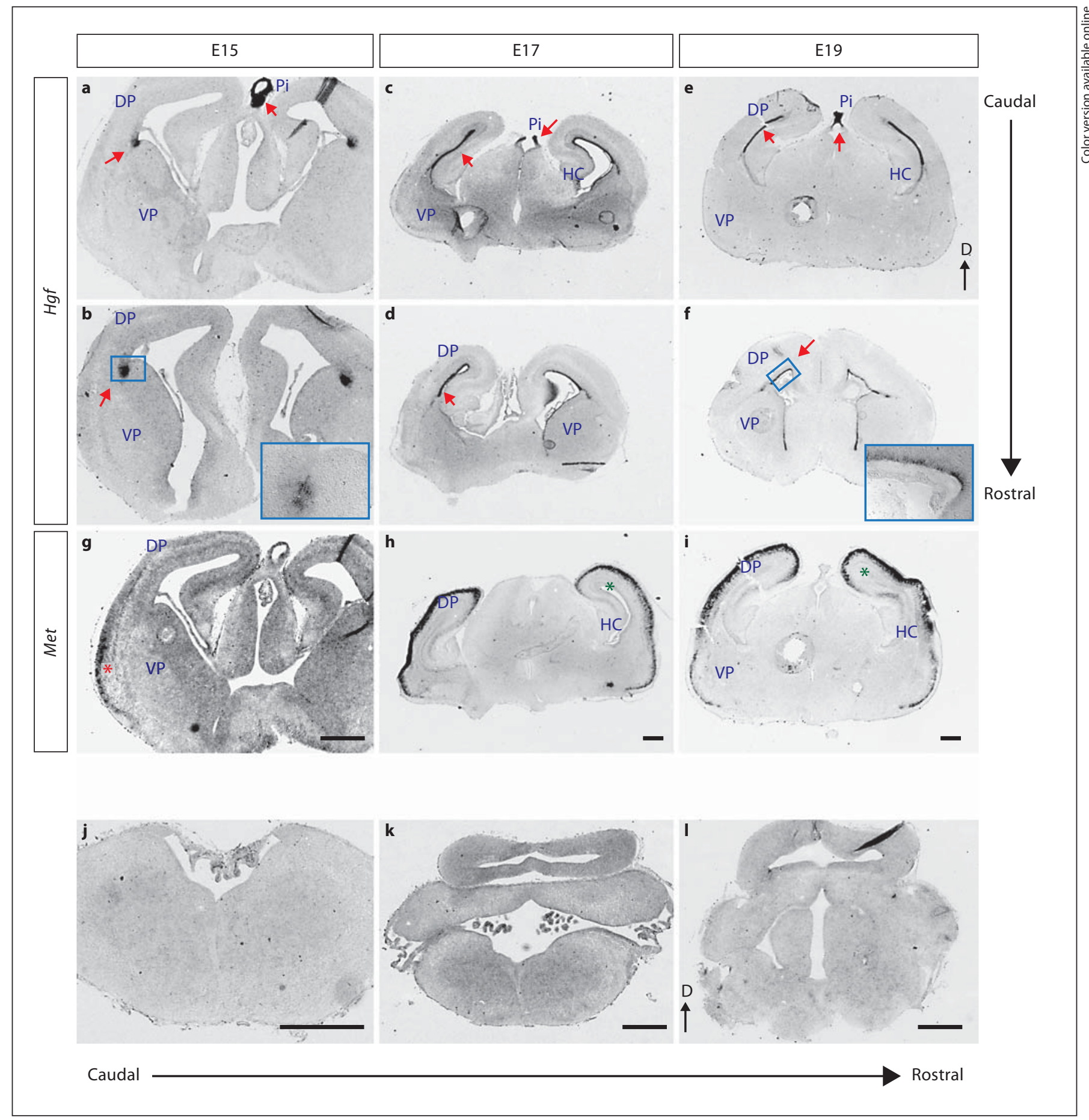

Fig. 6. Distribution of $H g f m R N A$ in the prenatal mouse forebrain. Coronal sections from E15 (a, b), E17 (c, d) and E19 (e, f) brains hybridized with a DIG-labeled riboprobe to full-length $\mathrm{Hgf}$ transcripts. g-i Met mRNA expression on adjacent sections of $\mathbf{a}, \mathbf{c}$ and e, respectively. $\mathrm{DP}=$ Dorsal pallium; $\mathrm{VP}=$ ventral pallium; $\mathrm{HC}=$ hippocampus; $\mathrm{Pi}$ = developing pineal gland. Higher-magnification images of boxed areas are shown in the right bottom corner of each micrograph. Arrows denote areas of intense $\mathrm{Hgflabeling.} \mathrm{Asterisks}$ indicate Met transcript localization. j-I Similarly stained caudal sections at E16 show that $H g f$ is not expressed in the midbrain and hindbrain. Absence of labeling was also evident at earlier and later prenatal ages. Dorsal (D) is at the top. Scale bar $=50 \mu \mathrm{m}$. 


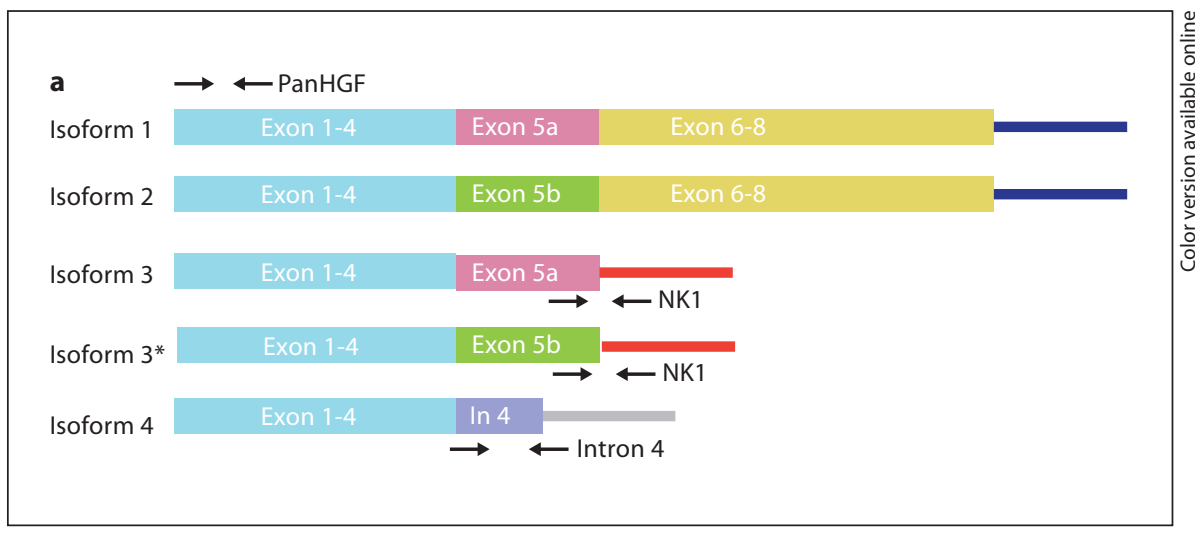

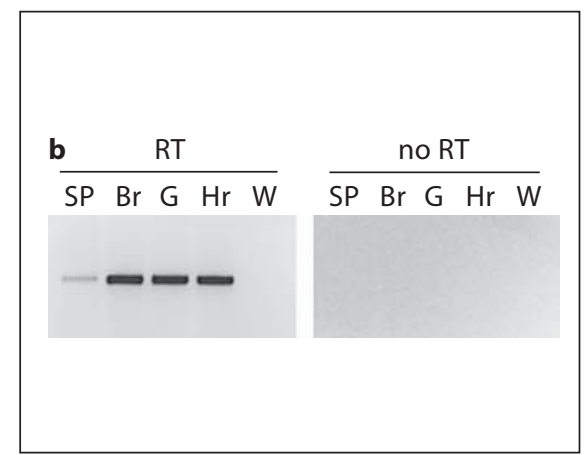

Fig. 7. Expression of full-length and splice variants of $\mathrm{Hgf}$ in the developing brain and visceral organs. a Diagram of the various forms of $\mathrm{Hgf}$. Relative positions of primer sets used for RT-PCR are indicated by arrows. Isoform $3^{*}$ was newly discovered by sequencing the PCR product and it is not reported in the UCSC mouse genome browser. b RT-PCR analysis of E16 CNS and visceral organ tissues for $H g f$ transcript expression using a pan $H g f$

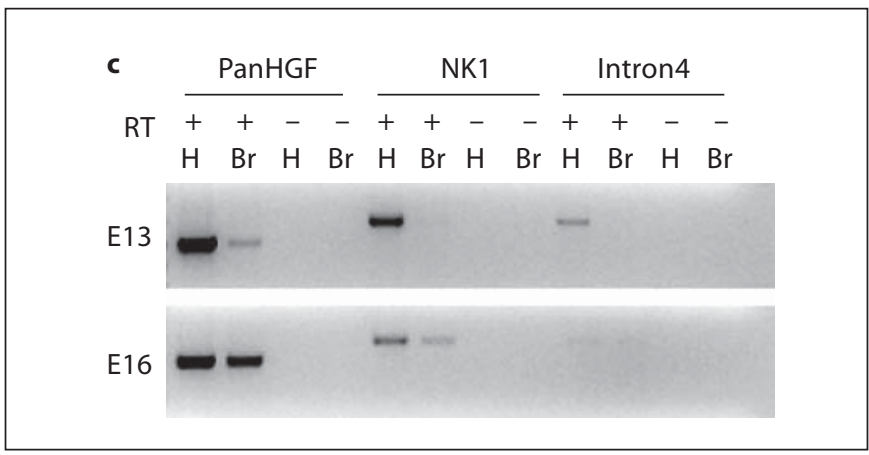

primer set. $\mathrm{SP}=$ Whole spinal cord; $\mathrm{Br}=$ whole brain; $\mathrm{G}=$ whole gut; $\mathrm{Hr}=$ whole heart. $\mathbf{c}$ RT-PCR expression analysis of $\mathrm{Hgf}$ splice variants in E13 and E16 whole-brain and head muscle/mesenchymal tissues. $\mathrm{RT}=$ Reverse transcriptase; $\mathrm{H}=$ head muscle/mesen-

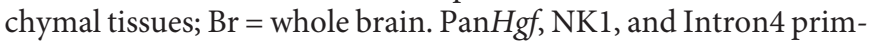
er sets are shown in $\mathbf{a}$. clei are involved in sensory and motor connections to visceral organs and the spinal cord. This has important functional implications, particularly in the context of neurodevelopmental disorders in which MET dysfunction has been implicated as a risk factor, such as ASD [18-20]. Expression of Met in these nuclei was detected first at E11 for DMV and nA [36], E13 for nTS, and E15 for BN, at the time when the corresponding neurons are postmitotic, have initiated axonal extensions, and are beginning to target peripheral structures [37]. Previous studies have shown that MET activation regulates axonal outgrowth by spinal and cranial facial motor neurons in vitro [36, 38]. In vivo, axonal targeting by neurons in nXII and spinal motor neurons innervating cutaneous maximus is disrupted by the absence of Met [36, 71]. Nonetheless, widespread axon pathfinding defects have not been described in either Hgf or Met knockout mice. Because con- stitutive deletion of $\mathrm{Hgf}$ or Met results in early lethality $[36,71]$, conditional deletion of Met will be required to examine its role in mediating maturation of brainstem visceral sensory/motor neurons during pre- and postnatal development.

The role of HGF-MET signaling during development in peripheral organs is not fully understood, though an early study first reported $\mathrm{Hg}$ expression in fetal kidney, intestine, lung, liver, pancreas and stomach [68]. This expression was confirmed in the present study using RTPCR (fig. 7). Given the localization of MET in motor neurons that innervate these structures, one may speculate a potentially important developmental impact of MET signaling on the extent or innervation patterns of motor axons. For example, the vagal nerve controls gastrointestinal (GI) peristalsis, while nTS receives the sensory information from the GI tract, relaying input to DMV and $\mathrm{nA}$. 
In this context, it is noteworthy that there is an increased association of MET rs1858830 C allele in children with ASD who exhibit co-occurring gastrointestinal conditions [21]. These children exhibit severe constipation as their primary GI condition [32, 33, 72], consistent with some contribution from the atypical development of MET-expressing circuits that are involved in mediating GI motility and visceral sensory functions. Moreover, in the context of expression in additional brainstem neuron groups, other autonomic problems are widely reported in children with ASD [29-31].

\section{MET, HGF and the Oral Sensory/Motor Circuitry}

Neurons located in nVII, nA and nXII innervate muscles in the oral tract such as the tongue, pharynx and larynx that control taste, eating, swallowing and speech. The specific expression of Met in subsets of neurons in these nuclei thus warrants further investigation in animals carrying conditionally deleted Met alleles. The function of MET may be even more selective and complex, however, because only subpopulations of neurons in these motor nuclei express Met. What may be the functional significance of such differential Met expression? It is possible that MET signaling acts only on certain subtypes of neurons in these motor nuclei. For example, in the dorsal root ganglia, MET signaling promotes peptidergic identity in a subset of nociceptors due to its ability to suppress Runx 1 expression [73]. In contrast, Runx1 represses Met expression in nonpeptidergic neurons. This counterbalance between Runx1 and MET signaling creates mixed populations of dorsal root ganglia neurons, consistent with MET signaling regulating the survival and differentiation of functionally related subsets of motor neurons in these brainstem nuclei. Cranial motor neurons develop early and have reached their target tissues by E13. Interestingly, only nXII nerves showed targeting defect at E12 in $\mathrm{Hgf}$ knockout mice [36]. Our results show that MET expression in these central motor nuclei extends through birth, suggesting that MET/HGF signaling may exert a role beyond the initial chemoattraction of cranial motor nerves.

\section{Met and DR 5-HT Projection}

Expression of Met transcript and protein occurs in a highly circumscribed region of the caudal DR 5-HT that includes neurons corresponding to the B6 subgroup. 5-HT neurons are involved in homeostatic, stress and mood regulation. Tracing experiments have shown specific projections from B6 5-HT neurons to the nucleus accumbens, amygdala, hypothalamus and medial prefrontal cortex, structures involved in emotional state and stress regulation [74, 75]. Furthermore, our results show an absence of MET expression in the Pet-1KO mouse, suggesting that Met transcription is downstream of this factor shown to be critical for the differentiation of the majority of rostrally projecting raphe neurons. The role of MET signaling in 5-HT neurons is not known. While not yet explored, the high level of G-protein-coupled 5-HT receptors in 5-HT neurons suggest a ligand-independent, alternative way to activate MET receptor as has been demonstrated in human hepatocellular and pancreatic carcinoma cells [76].

\section{HGF as a Putative CNS Signaling Molecule in Development}

Although MET activity has been linked to a variety of histogenic events [15], the developmental expression of its only known ligand, HGF, has not been examined thoroughly. In this study, we found that $H g f$ expression in the fetal CNS specifically localized to 2 regions: the developing pineal gland (starting at E13; fig. 6a, c, e) and cells along the ventricular/subventricular zone of the lateral ventricles. The current report did not examine early postnatal expression in the forebrain, a time when high levels of MET signaling influence later events of dendrite and synapse development [16]. Met deletion conditionally from the dorsal pallium does not result in major disruption of forebrain architecture and axon patterning [16]. Thus, the function of MET activation via HGF in this region of the developing forebrain appears to be more subtle. In addition to its abundance in serum, HGF is also present in cerebrospinal fluid $[77,78]$. This raises the possibility that HGF produced near the lateral ventricles and in the developing pineal gland, situated above the third ventricle, may be secreted into the cerebrospinal fluid and initiate signaling in distant regions of the embryonic brain. Interestingly, HGF in human cerebrospinal fluid can be detected, and levels were decreased in children with ASD [79].

The present data also provide the first evidence that there are multiple forms of $H g f$ transcript expressed during fetal brain development. In humans, according to the UCSC human genome browser (www.genome.ucsc.edu), 7 HGF mRNA splicing isoforms encode 7 different protein isoforms. Besides the two full-length forms of HGF that have been confirmed as MET ligands, the 2 smaller isoforms, $\mathrm{HGF} / \mathrm{NK} 1$ and $\mathrm{HGF} / \mathrm{NK} 2$ also can activate the receptor in vitro $[41,80,81]$. In addition, $\mathrm{HGF} / \mathrm{NK} 2$ can act as an antagonist to full-length HGF in vitro [82]. In mice, only 4 HGF protein isoforms generated from alternative splicing are reported in the UCSC mouse genome 
browser (fig. 7a). Our result shows that, in addition to $\mathrm{Hgf} / \mathrm{NK} 1$ (isoform 3; fig. 7a), another short Hgf splice variant (isoform 4; fig. 7a) is present in the developing mouse brain. These smaller polypeptides are similar in length (less than $25 \mathrm{kDa}$ ) to other growth factors, including FGFs, neurotrophins and TGF- $\beta$ family members. Future functional studies will determine whether short HGF isoforms exert biological actions on MET-expressing neurons.

\section{Conclusion}

Expression-mapping studies such as the one presented here provide a foundation for experimental manipulations that probe function. The challenge will be to translate our findings of robust MET expression in a limited number of brainstem nuclei that participate in homeo- static, visceral and autonomic regulation, combined with the very restricted expression of HGF to relevant peripheral structures and ventricular regions of the forebrain. MET signaling is pleiotropic, and thus may influence a complex number of histogenic events in brainstem nuclei. The variety of HGF ligands in the brain adds to the challenge of understanding MET developmental function.

\section{Acknowledgements}

We would like to thank Drs. Alexandre Bonnin and Kathie Eagleson (University of Southern California) and Linda Rinaman (University of Pittsburgh) for helpful discussions and comments on the manuscript. This work was supported by the Hearing Health Foundation (formally Deafness Research Foundation) research grant and Zumberge individual awards $(\mathrm{H} .-\mathrm{H} . \mathrm{Wu})$, and NIMH grant MH067842 (P. Levitt).

\section{References}

1 Cooper CS, Blair DG, Oskarsson MK, Tainsky MA, Eader LA, Vande Woude GF: Characterization of human transforming genes from chemically transformed, teratocarcinoma, and pancreatic carcinoma cell lines. Cancer Res 1984;44:1-10.

-2 Cooper CS, Park M, Blair DG, Tainsky MA, Huebner K, Croce CM, Vande Woude GF: Molecular cloning of a new transforming gene from a chemically transformed human cell line. Nature 1984;311:29-33.

-3 Stoker M, Perryman M: An epithelial scatter factor released by embryo fibroblasts. J Cell Sci 1985;77:209-223.

4 Nakamura T, Nawa K, Ichihara A, Kaise N, Nishino T: Purification and subunit structure of hepatocyte growth factor from rat platelets. FEBS Lett 1987;224:311-316.

-5 Nakamura T, Nishizawa T, Hagiya M, Seki T, Shimonishi M, Sugimura A, Tashiro K, Shimizu S: Molecular cloning and expression of human hepatocyte growth factor. Nature 1989;342:440-443.

6 Stoker M, Gherardi E, Perryman M, Gray J: Scatter factor is a fibroblast-derived modulator of epithelial cell mobility. Nature 1987; 327:239-242.

7 Abounader R, Laterra J: Scatter factor/hepatocyte growth factor in brain tumor growth and angiogenesis. Neuro Oncol 2005;7:436451.

8 Birchmeier C, Birchmeier W, Gherardi E, Vande Woude GF: Met, metastasis, motility and more. Nat Rev Mol Cell Biol 2003;4:915925.

-9 Schmidt C, Bladt F, Goedecke S, Brinkmann V, Zschiesche W, Sharpe M, Gherardi E,
Birchmeier C: Scatter factor/hepatocyte growth factor is essential for liver development. Nature 1995;373:699-702.

10 Birchmeier C, Gherardi E: Developmental roles of HGF/SF and its receptor, the c-Met tyrosine kinase. Trends Cell Biol 1998;8:404410.

11 Bladt F, Riethmacher D, Isenmann S, Aguzzi A, Birchmeier C: Essential role for the c-met receptor in the migration of myogenic precursor cells into the limb bud. Nature 1995; 376:768-771.

12 Gentile A, Trusolino L, Comoglio PM: The Met tyrosine kinase receptor in development and cancer. Cancer Metastasis Rev 2008;27: 85-94.

13 Trusolino L, Bertotti A, Comoglio PM: Met signalling: principles and functions in development, organ regeneration and cancer. Nat Rev Mol Cell Biol 2010;11:834-848.

14 Benvenuti S, Comoglio PM: The MET receptor tyrosine kinase in invasion and metastasis. J Cell Physiol 2007;213:316-325.

15 Judson MC, Eagleson KL, Levitt P: A new synaptic player leading to autism risk: Met receptor tyrosine kinase. J Neurodev Disord 2011; 3:282-292.

16 Judson MC, Eagleson KL, Wang L, Levitt P: Evidence of cell-nonautonomous changes in dendrite and dendritic spine morphology in the met-signaling-deficient mouse forebrain. J Comp Neurol 2010;518:4463-4478.

17 Qiu S, Anderson CT, Levitt P, Shepherd GM: Circuit-specific intracortical hyperconnectivity in mice with deletion of the autism-associated met receptor tyrosine kinase. J Neurosci 2011;31:5855-5864.
18 Campbell DB, Sutcliffe JS, Ebert PJ, Militerni R, Bravaccio C, Trillo S, Elia M, Schneider C, Melmed R, Sacco R, Persico AM, Levitt P: A genetic variant that disrupts met transcription is associated with autism. Proc Natl Acad Sci USA 2006;103:16834-16839.

19 Campbell DB, Li C, Sutcliffe JS, Persico AM, Levitt P: Genetic evidence implicating multiple genes in the met receptor tyrosine kinase pathway in autism spectrum disorder. Autism Res 2008; 1:159-168.

20 Jackson PB, Boccuto L, Skinner C, Collins JS, Neri G, Gurrieri F, Schwartz CE: Further evidence that the rs $1858830 \mathrm{c}$ variant in the promoter region of the met gene is associated with autistic disorder. Autism Res 2009;2: 232-236.

21 Campbell DB, Buie TM, Winter H, Bauman M, Sutcliffe JS, Perrin JM, Levitt P: Distinct genetic risk based on association of met in families with co-occurring autism and gastrointestinal conditions. Pediatrics 2009;123: 1018-1024.

22 Campbell DB, D’Oronzio R, Garbett K, Ebert PJ, Mirnics K, Levitt P, Persico AM: Disruption of cerebral cortex met signaling in autism spectrum disorder. Ann Neurol 2007;62:243250

23 Voineagu I, Wang X, Johnston P, Lowe JK, Tian Y, Horvath S, Mill J, Cantor RM, Blencowe BJ, Geschwind DH: Transcriptomic analysis of autistic brain reveals convergent molecular pathology. Nature 2011;474:380-384.

24 Xu LM, Li JR, Huang Y, Zhao M, Tang X, Wei L: Autismkb: An evidence-based knowledgebase of autism genetics. Nucleic Acids Res 2012;40:D1016-D1022. 
-25 Judson MC, Bergman MY, Campbell DB, Eagleson KL, Levitt P: Dynamic gene and protein expression patterns of the autism-associated met receptor tyrosine kinase in the developing mouse forebrain. J Comp Neurol 2009; 513:511-531.

-26 Judson MC, Amaral DG, Levitt P: Conserved subcortical and divergent cortical expression of proteins encoded by orthologs of the autism risk gene met. Cereb Cortex 2011;21: 1613-1626.

-27 Roth DA, Muchnik C, Shabtai E, Hildesheimer M, Henkin Y: Evidence for atypical auditory brainstem responses in young children with suspected autism spectrum disorders. Dev Med Child Neurol 2012;54:23-29.

-28 Ploeger A, Raijmakers ME, van der Maas HL, Galis F: The association between autism and errors in early embryogenesis: what is the causal mechanism? Biol Psychiatry 2010;67: 602-607.

29 Geschwind DH: Advances in autism. Annu Rev Med 2009;60:367-380.

- 30 Porges SW, Furman SA: The early development of the autonomic nervous system provides a neural platform for social behavior: a polyvagal perspective. Infant Child Dev 2011; 20:106-118.

- 31 Bal E, Harden E, Lamb D, Van Hecke AV, Denver JW, Porges SW: Emotion recognition in children with autism spectrum disorders: relations to eye gaze and autonomic state. J Autism Dev Disord 2010;40:358-370.

-32 Pang KH, Croaker GD: Constipation in children with autism and autistic spectrum disorder. Pediatr Surg Int 2011;27:353-358.

33 Wang LW, Tancredi DJ, Thomas DW: The prevalence of gastrointestinal problems in children across the United States with autism spectrum disorders from families with multiple affected members. J Dev Behav Pediatr 2011;32:351-360.

-34 Mayer EA: Gut feelings: the emerging biology of gut-brain communication. Nat Rev Neurosci 2011;12:453-466.

35 Mayer EA, Tillisch K: The brain-gut axis in abdominal pain syndromes. Annu Rev Med 2011;62:381-396.

36 Caton A, Hacker A, Naeem A, Livet J, Maina F, Bladt F, Klein R, Birchmeier C, Guthrie S: The branchial arches and HGF are growthpromoting and chemoattractant for cranial motor axons. Development 2000;127:17511766.

37 Pierce ET: Time of origin of neurons in the brain stem of the mouse. Prog Brain Res 1973; 40:53-65.

- 38 Ebens A, Brose K, Leonardo ED, Hanson MG Jr, Bladt F, Birchmeier C, Barres BA, TessierLavigne M: Hepatocyte growth factor/scatter factor is an axonal chemoattractant and a neurotrophic factor for spinal motor neurons. Neuron 1996;17:1157-1172.

-39 Elsen GE, Choi LY, Prince VE, Ho RK: The autism susceptibility gene met regulates zebrafish cerebellar development and facial motor neuron migration. Dev Biol 2009;335:78-92.
40 Schwall RH, Chang LY, Godowski PJ, Kahn DW, Hillan KJ, Bauer KD, Zioncheck TF: Heparin induces dimerization and confers proliferative activity onto the hepatocyte growth factor antagonists NK1 and NK2. J Cell Biol 1996;133:709-718.

41 Jakubczak JL, LaRochelle WJ, Merlino G: NK1, a natural splice variant of hepatocyte growth factor/scatter factor, is a partial agonist in vivo. Mol Cell Biol 1998;18:1275-1283.

42 Schultz JM, Khan SN, Ahmed ZM, Riazuddin S, Waryah AM, Chhatre D, Starost MF, Ploplis B, Buckley S, Velasquez D, Kabra M, Lee K, Hassan MJ, Ali G, Ansar M, Ghosh M, Wilcox ER, Ahmad W, Merlino G, Leal SM, Friedman TB, Morell RJ: Noncoding mutations of HGF are associated with nonsyndromic hearing loss, DFNB39. Am J Hum Genet 2009;85: 25-39.

43 Gaddy DF, Riedel MJ, Pejawar-Gaddy S, Kieffer TJ, Robbins PD: In vivo expression of HGF/NK1 and GLP-1 from dsAAV vectors enhances pancreatic $\beta$-cell proliferation and improves pathology in the $\mathrm{db} / \mathrm{db}$ mouse model of diabetes. Diabetes 2010;59:3108-3116.

44 Yang L, Cai CL, Lin L, Qyang Y, Chung C, Monteiro RM, Mummery CL, Fishman GI, Cogen A, Evans S: Isl1Cre reveals a common Bmp pathway in heart and limb development. Development 2006;133:1575-1585.

45 Madisen L, Zwingman TA, Sunkin SM, Oh SW, Zariwala HA, Gu H, Ng LL, Palmiter RD, Hawrylycz MJ, Jones AR, Lein ES, Zeng H: A robust and high-throughput Cre reporting and characterization system for the whole mouse brain. Nat Neurosci 2010;13:133-140.

46 Hendricks TJ, Fyodorov DV, Wegman LJ, Lelutiu NB, Pehek EA, Yamamoto B, Silver J, Weeber EJ, Sweatt JD, Deneris ES: Pet-1 ETS gene plays a critical role in 5-HT neuron development and is required for normal anxiety-like and aggressive behavior. Neuron 2003;37:233-247.

$47 \mathrm{Wu}$ HH, Bellmunt E, Scheib JL, Venegas V, Burkert C, Reichardt LF, Zhou Z, Farinas I, Carter BD: Glial precursors clear sensory neuron corpses during development via Jedi-1, an engulfment receptor. Nat Neurosci 2009;12: 1534-1541.

48 Jacobowitz D, Abbott L: Chemoarchitectonic Atlas of the Developing Mouse Brain. Boca Raton, CRC Press, 1997.

49 Varela-Echavarria A, Pfaff SL, Guthrie S: Differential expression of LIM homeobox genes among motor neuron subpopulations in the developing chick brain stem. Mol Cell Neurosci 1996;8:242-257.

50 Troy CM, Brown K, Greene LA, Shelanski ML: Ontogeny of the neuronal intermediate filament protein, peripherin, in the mouse embryo. Neuroscience 1990;36:217-237.

51 Barclay M, Noakes PG, Ryan AF, Julien JP, Housley GD: Neuronal expression of peripherin, a type III intermediate filament protein, in the mouse hindbrain. Histochem Cell Biol 2007; 128:541-550.
52 Dauger S, Pattyn A, Lofaso F, Gaultier C, Goridis C, Gallego J, Brunet JF: Phox 2b controls the development of peripheral chemoreceptors and afferent visceral pathways. Development 2003; 130:6635-6642.

53 Bradley RM: Historical perspectives; in Bradley RM (ed): The Role of the Nucleus of the Solitary Tract in Gustatory Processing. Boca Raton, CRC Press, 2007.

54 Herbert H, Moga MM, Saper CB: Connections of the parabrachial nucleus with the nucleus of the solitary tract and the medullary reticular formation in the rat. J Comp Neurol 1990;293:540-580.

55 Sieber MA, Storm R, Martinez-de-la-Torre M, Muller T, Wende H, Reuter K, Vasyutina E, Birchmeier C: Lbx1 acts as a selector gene in the fate determination of somatosensory and viscerosensory relay neurons in the hindbrain. J Neurosci 2007;27:4902-4909.

56 Cordes SP: Molecular genetics of cranial nerve development in mouse. Nat Rev Neurosci 2001;2:611-623.

57 Dahlstrom A, Fuxe K: Localization of monoamines in the lower brain stem. Experientia 1964;20:398-399.

58 Taber E, Brodal A, Walberg F: The raphe nuclei of the brain stem in the cat. I. Normal topography and cytoarchitecture and general discussion. J Comp Neurol 1960;114:161187.

59 Levitt P, Moore RY: Developmental organization of raphe serotonin neuron groups in the rat. Anat Embryol 1978;154:241-251.

60 Sugaya K, Matsuyama K, Takakusaki K, Mori $S$ : Electrical and chemical stimulations of the pontine micturition center. Neurosci Lett 1987;80:197-201.

61 Noto H, Roppolo JR, Steers WD, de Groat WC: Excitatory and inhibitory influences on bladder activity elicited by electrical stimulation in the pontine micturition center in the rat. Brain Res 1989;492:99-115.

62 Noto H, Roppolo JR, Steers WD, de Groat WC: Electrophysiological analysis of the ascending and descending components of the micturition reflex pathway in the rat. Brain Res 1991;549:95-105.

63 Cano G, Card JP, Rinaman L, Sved AF: Connections of Barrington's nucleus to the sympathetic nervous system in rats. J Auton Nery Syst 2000;79:117-128.

64 Rose MF, Ahmad KA, Thaller C, Zoghbi HY: Excitatory neurons of the proprioceptive, interoceptive, and arousal hindbrain networks share a developmental requirement for Math1. Proc Natl Acad Sci USA 2009;106: 22462-22467.

65 Sawchenko PE, Imaki T, Potter E, Kovacs K, Imaki J, Vale W: The functional neuroanatomy of corticotropin-releasing factor. Ciba Found Symp 1993;172:5-21, discussion pp 21-29.

66 Sved AF, Cano G, Passerin AM, Rabin BS: The locus coeruleus, Barrington's nucleus, and neural circuits of stress. Physiol Behav 2002; 77:737-742.
Met Expression in the Developing Brainstem
Dev Neurosci 2013;35:1-16 DOI: $10.1159 / 000346367$ 
67 Weidner KM, Sachs M, Birchmeier W: The Met receptor tyrosine kinase transduces motility, proliferation, and morphogenic signals of scatter factor/hepatocyte growth factor in epithelial cells. J Cell Biol 1993;121:145-154.

68 Sonnenberg E, Meyer D, Weidner KM, Birchmeier C: Scatter factor/hepatocyte growth factor and its receptor, the c-met tyrosine $\mathrm{ki}$ nase, can mediate a signal exchange between mesenchyme and epithelia during mouse development. J Cell Biol 1993;123:223-235.

69 Stenman J, Yu RT, Evans RM, Campbell K: Tlx and Pax6 co-operate genetically to establish the pallio-subpallial boundary in the embryonic mouse telencephalon. Development 2003;130:1113-1122.

70 Chan AM, Rubin JS, Bottaro DP, Hirschfield DW, Chedid M, Aaronson SA: Identification of a competitive HGF antagonist encoded by an alternative transcript. Science 1991;254: 1382-1385.

71 Lamballe F, Genestine M, Caruso N, Arce V, Richelme S, Helmbacher F, Maina F: Poolspecific regulation of motor neuron survival by neurotrophic support. J Neurosci 2011;31: 11144-11158.
72 Gorrindo P, Williams KC, Lee EB, Walker LS, McGrew SG, Levitt P: Gastrointestinal dysfunction in autism: parental report, clinical evaluation, and associated factors. Autism Res 2012;5:101-108.

73 Gascon E, Gaillard S, Malapert P, Liu Y, Rodat-Despoix L, Samokhvalov IM, Delmas P, Helmbacher F, Maina F, Moqrich A: Hepatocyte growth factor-Met signaling is required for Runx1 extinction and peptidergic differentiation in primary nociceptive neurons. J Neurosci 2010;30:12414-12423.

74 Waselus M, Valentino RJ, Van Bockstaele EJ: Collateralized dorsal raphe nucleus projections: a mechanism for the integration of diverse functions during stress. J Chem Neuroanat 2011;41:266-280.

75 Van Bockstaele EJ, Biswas A, Pickel VM: Topography of serotonin neurons in the dorsal raphe nucleus that send axon collaterals to the rat prefrontal cortex and nucleus accumbens. Brain Res 1993;624:188-198.

76 Fischer OM, Giordano S, Comoglio PM, Ullrich A: Reactive oxygen species mediate Met receptor transactivation by $\mathrm{G}$ protein-coupled receptors and the epidermal growth factor receptor in human carcinoma cells. J Biol Chem 2004;279:28970-28978.

-77 Tsuboi Y, Kakimoto K, Akatsu H, Daikuhara Y, Yamada T: Hepatocyte growth factor in cerebrospinal fluid in neurologic disease. Acta Neurol Scand 2002;106:99-103.
78 Kern MA, Bamborschke S, Nekic M, Schubert D, Rydin C, Lindholm D, Schirmacher P: Concentrations of hepatocyte growth factor in cerebrospinal fluid under normal and different pathological conditions. Cytokine 2001;14:170-176.

79 Vargas DL, Nascimbene C, Krishnan C, Zimmerman AW, Pardo CA: Neuroglial activation and neuroinflammation in the brain of patients with autism. Ann Neurol 2005;57: 67-81.

80 Miyazawa K, Kitamura A, Naka D, Kitamura $\mathrm{N}$ : An alternatively processed mRNA generated from human hepatocyte growth factor gene. Eur J Biochem 1991;197:15-22.

81 Lokker NA, Mark MR, Luis EA, Bennett GL, Robbins KA, Baker JB, Godowski PJ: Structure-function analysis of hepatocyte growth factor: identification of variants that lack mitogenic activity yet retain high affinity receptor binding. EMBO J 1992;11:2503-2510.

82 Cioce V, Csaky KG, Chan AM, Bottaro DP, Taylor WG, Jensen R, Aaronson SA, Rubin JS: Hepatocyte growth factor (HGF)/NK1 is a naturally occurring $\mathrm{HGF} / \mathrm{scatter}$ factor variant with partial agonist/antagonist activity. J Biol Chem 1996;271:13110-13115. 